\title{
High Potassium, Calcium, and Nitrogen Application Reduce Susceptibility to Banana Xanthomonas Wilt Caused by Xanthomonas campestris pv. musacearum
}

Margaret Atim, International Institute of Tropical Agriculture and Makerere University, Kampala, Uganda; and National Crops Resources Research Institute, Namulonge, Uganda; Fen Beed, International Institute of Tropical Agriculture; Geoffrey Tusiime, Makerere University, Kampala; and Leena Tripathi and Piet van Asten, International Institute of Tropical Agriculture

\begin{abstract}
Atim, M., Beed, F., Tusiime, G., Tripathi, L., and van Asten, P. 2013. High potassium, calcium, and nitrogen application reduce susceptibility to banana Xanthomonas wilt caused by Xanthomonas campestris pv. musacearum. Plant Dis. 97:123-130.

The effect of exogenous applications of potassium $(\mathrm{K})$, calcium $(\mathrm{Ca})$, and nitrogen $(\mathrm{N})$ on the susceptibility of four banana cultivars to Banana Xanthomonas wilt (BXW) was studied. Murashige and Skoog (MS) medium with normal concentrations of $\mathrm{K}$ at $783 \mathrm{mg} / \mathrm{liter}$, Ca at $121 \mathrm{mg} / \mathrm{liter}$, and $\mathrm{N}$ at $841 \mathrm{mg} / \mathrm{liter}$ was modified to contain various concentrations of $\mathrm{K}, \mathrm{Ca}$, and $\mathrm{N}$. Each nutrient was varied singly, each with three replicate experiments. The concentrations were $\mathrm{K}$ at 78 , 157, 391, 783, 1,565, and 3,913 mg/liter; Ca at 12, 24, 60, 121, 241, and $603 \mathrm{mg} / \mathrm{liter}$; and $\mathrm{N}$ at $84,168,420,841$, and 1,682 mg/liter. Plantlets were generated in vitro on normal MS medium and later exposed

to the nutrient concentrations for a total of 8 weeks. Thereafter, they were artificially inoculated with Xanthomonas campestris pv. musacearum using an insulin syringe. In each nutrient, plantlets exposed to higher nutrient concentrations significantly $(P<0.0001)$ accumulated more nutrient in their tissues compared with those exposed to lesser nutrient concentrations. Wilt incidences were significantly reduced, and incubation periods (time from inoculation to appearance of first disease symptoms) increased, with increasing nutrient application. The study lays a background for in vivo studies aimed at management of BXW using nutrients, such as fertilizer application.
\end{abstract}

Banana, including plantain (Musa spp.), is an important source of food and income. Its annual world production is estimated at 127 million tons (t) (16), with Uganda being Africa's largest producer (9.9 million t/annum) and ranking second in the world after India. Most production is for local consumption and the annual per capita consumption of banana in Uganda is $191 \mathrm{~kg}$ (15). Despite the great importance of banana in Uganda, its production is decreasing because of soil nutrient depletion $(4,6,28,44,45)$ and weevil (Cosmopolites sordidus) and nematode infestations (34). Its productivity has further been constrained by diseases such as black and yellow Sigatoka, Fusarium wilt, and, most recently, banana Xanthomonas wilt (BXW) caused by Xanthomonas campestris pv. musacearum (42). The International Food Policy Research Institute (20) lists BXW and soil nutrient depletion as the greatest threats to banana production in Uganda, causing yield losses of up to 80 to $100 \%$ and 10 to $70 \%$, respectively.

Having first been reported on Ensete, a close relative of banana, in Ethiopia in 1968 and later on banana (49), BXW spread rapidly through Uganda in 2001 (42) and to Democratic Republic of Congo (27), Rwanda (32), Burundi, Tanzania, and Kenya (9). The disease, which is characterized by yellowing and wilting of leaves and premature ripening and rotting of bunches $(39,42)$, is very destructive and renders the affected fruit inedible, leading to complete yield losses (43). All banana cultivars in Uganda are susceptible to the disease (36).

Current control measures include removal of the male bud (debudding) to prevent insect transmission, removal of symptomatic plants to reduce inoculum, use of clean planting materials, and disinfection of tools after use from one mat to another so as to

Corresponding author: M. Atim, E-mail: atimmargie@yahoo.com

* The $\boldsymbol{e}$-Xtra logo stands for "electronic extra" and indicates that Figures 1 and 3 appear in color in the online edition.

Accepted for publication 13 August 2012.

http://dx.doi.org/10.1094/PDIS-07-12-0646-RE

(C) 2013 The American Phytopathological Society prevent spread from one plant to another. However, the adherence of farmers to these control measures has been difficult because they are time consuming (7). Debudding, which is often done late or not at all (22), is culturally believed to reduce the quality of banana juice made from debudded bunches (26). Integrated control measures have been suggested to be more efficient for the management of banana diseases (12). Improving the plant's mineral nutrition has been suggested as a component of an integrated control package to fight fungal and bacterial diseases in several crops, including wilts and other diseases caused by xanthomonads $(13,14)$. Nutrients are essential for plant growth and physiological and metabolic processes, including disease resistance $(2,13,14)$. Increased application of several nutrients such as nitrogen $(\mathrm{N})$, potassium $(\mathrm{K})$, calcium $(\mathrm{Ca})$, manganese $(\mathrm{Mn})$, silicon $(\mathrm{Si})$, boron (B), and chloride $(\mathrm{Cl})$ have had a disease-reducing effect on a number of plants (13).

The banana plant requires and accumulates high levels of $\mathrm{K}$ and $\mathrm{N}$ in its tissues $(4,23)$. These nutrients are unfortunately facing depletion in Ugandan soils $(5,6)$. Addition of these nutrients to soil can potentially play a dual role of improving soil fertility and reducing diseases, thereby increasing yield $(35,45)$. The effect of such mineral nutrients on the susceptibility of banana plants to BXW disease is not yet known. This study was conducted to determine the effect of exogenously applied $\mathrm{K}, \mathrm{Ca}$, and $\mathrm{N}$ on plant nutrition and subsequent BXW expression in susceptible and moderately susceptible cultivars. An in vitro approach was chosen for this purpose, because nutrient concentrations can easily be manipulated in the growth medium and because the sensitive young plantlets allow a rapid response to nutrient variations in a well-controlled environment similar to plants in the soil or hydroponics $(18,37,46,47)$.

\section{Materials and Methods}

Experimental design. The experiment was designed as a completely randomized design with a balanced treatment structure. The effect of nutrient concentration on susceptibility of four banana cultivars to BXW was investigated. Each nutrient was varied one at a time to generate its different concentrations, while leaving the other nutrients at the normal Murashige and Skoog (MS) medium concentrations. For the varied nutrient, each concentration was 
replicated in three experiments and each replicate consisted of 15 plantlets of that cultivar. This was carried out for all the four banana cultivars and all three nutrients. Disease susceptibility was measured as BXW incidence (percentage of diseased plantlets), incubation period (time taken for BXW symptoms to first appear after inoculation), and time taken for diseased plantlets to die after the onset of BXW symptoms.

Plant material. The four banana cultivars used in this study were obtained from the disease-free, on-station germplasm fields at the National Agriculture Research Laboratories (NARL). They were chosen based on their level of susceptibility to BXW. These were 'Pisang awak' (commonly known as 'Kayinja', ABB) and 'FHIA-17' (AAAA) which are highly susceptible and susceptible, respectively; and two East African highland bananas, 'Mbwazirume' (AAA-EA) and 'Nakitembe' (AAA-EA), which are susceptible and moderately susceptible, respectively $(36,40)$. They were regenerated in vitro from meristems on MS medium (25) supplemented with 6-benzylaminopurine (6-BAP) at $2.5 \mathrm{mg} / \mathrm{liter}$ and ascorbic acid at $20 \mathrm{mg} / \mathrm{liter}$. The growth conditions included a 14-h photoperiod provided by fluorescent tubes $\left(94 \mu \mathrm{mol} \mathrm{m} \mathrm{m}^{-2} \mathrm{~s}^{-1}\right)$ and $26 \pm 2{ }^{\circ} \mathrm{C}$.

Nutrient application. Modifications were made to MS medium so as to generate different media of varying concentrations of the nutrients, $\mathrm{K}, \mathrm{Ca}$, and $\mathrm{N}$. Each nutrient was varied one at a time to generate new concentrations, including their normal concentrations used in MS medium for banana micropropagation. The normal concentrations are $\mathrm{K}$ at $783 \mathrm{mg} / \mathrm{liter}, \mathrm{Ca}$ at $121 \mathrm{mg} / \mathrm{liter}$, and $\mathrm{N}$ at $841 \mathrm{mg} / \mathrm{liter}$ and the new concentrations were $\mathrm{K}$ at 78, 157, 391, 1,565, and 3,913 mg/liter; $\mathrm{Ca}$ at 12, 24, 60, 241, and $603 \mathrm{mg} / \mathrm{liter}$; and $\mathrm{N}$ at $84,168,420$, and 1,682 $\mathrm{mg} /$ liter. The nutrient sources used in MS medium to provide the three nutrients were either increased or decreased to attain the desired nutrient concentrations (Table 1). Because each nutrient was varied singly, in cases of $\mathrm{K}$ and $\mathrm{N}$ which shared the same nutrient source $\left(\mathrm{KNO}_{3}\right)$ in MS medium, additional nutrient sources that are not normally used in MS medium such as potassium chloride $(\mathrm{KCl})$ and sodium dihydrogen phosphate $\left(\mathrm{NaH}_{2} \mathrm{PO}_{4}\right)$ were included in order to vary the concentration of the one target nutrient but not the other (Table 1). In order to avoid confounding results that may come about with variations in $\mathrm{pH}$ attributed to the varied nutrient concentrations (21), the $\mathrm{pH}$ of the media was uniformly adjusted to $5.8 \pm 0.02$ and solidified with gelrite (Duchefa Biochemie) at 2 to $3.5 \mathrm{~g} /$ liter. Gelrite concentration was increased from the normal 2 to $3.5 \mathrm{~g} / \mathrm{liter}$ in the higher nutrient concentrations of $\mathrm{K}$ at 1,565 and 3,913 $\mathrm{mg} / \mathrm{liter}, \mathrm{Ca}$ at 241 and $603 \mathrm{mg} / \mathrm{liter}$, and $\mathrm{N}$ at 1,682 $\mathrm{mg} / \mathrm{liter}$, because media could not solidify at the 2 -g/liter gelrite concentration. Medium (45 $\mathrm{ml}$ ) was dispensed into $150-\mathrm{ml}$ glass culture jars $(98.5$ by $59 \mathrm{~mm}$; Sigma-Aldrich). This was also done uniformly for all nutrient concentrations investigated.

Culture of plantlets on the different media of varied nutrient concentrations. The plantlets previously regenerated and multiplied on normal MS medium as described above were trimmed by removing the leaves and part of the pseudostem and roots so as to leave only a corm that contains the meristem. Four corms were placed in each glass culture jar containing $45 \mathrm{ml}$ of medium (Fig. 1A). The corms were kept on the medium for 4 weeks, by which time they had three to four leaves. Thereafter, they were transferred onto fresh medium of the same nutrient concentrations without trimming off any leaves for another 4 weeks (Fig. 1B). Therefore, plantlets were exposed to the target nutrient concentrations for a total of 8 weeks. The growth conditions were the same as those used for regeneration and multiplication of the plant material described above.

Plant tissue nutrient analysis. After 8 weeks of culture on the medium of varied nutrient concentrations, 5 to 10 plantlets for each nutrient concentration were taken at random and cut at the base of the pseudostem to remove the corm and roots. They were oven dried at $65^{\circ} \mathrm{C}$ for $72 \mathrm{~h}$. Thereafter, a composite sample from three replications totaling to $0.4 \pm 0.1 \mathrm{~g}$ of dry weight was taken for nutrient analysis. The samples were digested using Kjedahl oxidation and total $\mathrm{N}$ was determined using a spectrophotometer. Phosphorous was then determined colorimetrically using the molybdenum blue method and $\mathrm{K}$ using a flame photometer. The cations $\mathrm{Ca}$ and magnesium were determined using an atomic absorption spectrophotometer (29). This was carried out for all the nutrient concentrations.

Bacterial inoculum. Although all banana cultivars are susceptible at different levels to $X$. campestris pv. musacearum, there has been no evidence to date of genetic and pathogenic diversity in Ugandan $X$. campestris pv. musacearum isolates $(3,40)$. Therefore, only one isolate (from Wakiso district) obtained from NARL was used in the study. A pathogenicity test was carried out using this isolate with the susceptible Kayinja. This was repeated every 4 weeks. The isolate was maintained on yeast peptone glucose agar (YPGA) medium $(0.5 \%$ yeast, $0.5 \%$ peptone, $1 \%$ glucose, and $1.5 \%$ agar) at $4^{\circ} \mathrm{C}$ for 3 weeks. Prior to inoculation, $X$. campestris pv. musacearum was first cultured on YPGA for 3 days at $28^{\circ} \mathrm{C}$ in the dark and, thereafter, it was cultured overnight in $20 \mathrm{ml}$ of YPG broth in a 50-ml conical flask while shaking at $150 \mathrm{rpm}$ at a temperature of $28 \pm 2{ }^{\circ} \mathrm{C}$. They were then centrifuged at $4,025 \times g$ for $5 \mathrm{~min}$ and the cell pellet resuspended into sterile distilled water. The optical density at $600 \mathrm{~nm}$ of the suspension was then measured using a spectrophotometer (Biomate 3; Thermo Electron Corporation) and the bacterial concentration readjusted to $10^{8} \mathrm{CFU} / \mathrm{ml}$ using sterile distilled water.

Inoculation of the banana plantlets with $X$. campestris pv. musacearum. After 8 weeks of culture, while 5 to 10 plantlets of each cultivar for each nutrient concentration were taken for nutrient analysis above, another 15 plantlets for each cultivar and for each nutrient concentration were inoculated with $X$. campestris pv. musacearum according to the method described by Tripathi et al. (40). Using a sterile $1-\mathrm{ml}$ insulin syringe $(0.33$ by $12.7 \mathrm{~mm}$; BD Micro-Fine Plus), $50 \mu \mathrm{l}$ of $X$. campestris pv. musacearum cell suspensions of $10^{8} \mathrm{CFU} / \mathrm{ml}$ was inoculated into the lower part of the

Table 1. Mass ( $\mathrm{mg})$ of the nutrient source in 1 liter of medium modified to different concentrations of potassium $(\mathrm{K})$, calcium $(\mathrm{Ca})$, and nitrogen $(\mathrm{N})$

\begin{tabular}{|c|c|c|c|c|c|c|c|c|c|c|c|c|c|c|c|}
\hline \multirow[b]{3}{*}{ Source } & \multicolumn{15}{|c|}{ Nutrient concentration (mg/liter) } \\
\hline & \multirow[b]{2}{*}{$\operatorname{Norm}^{x}$} & \multicolumn{5}{|c|}{ Potassium } & \multicolumn{5}{|c|}{ Calcium } & \multicolumn{4}{|c|}{ Nitrogen } \\
\hline & & 78 & 157 & 391 & 1,565 & 3,913 & 12 & 24 & 60 & 241 & 603 & 84 & 168 & 420 & 1,682 \\
\hline $\mathrm{NH}_{4} \mathrm{NO}_{3}$ & 1,650 & 2,327 & 2,252 & 2,026 & 1,650 & 1,650 & 1,650 & 1,650 & 1,650 & 1,650 & 1,650 & 165 & 330 & 825 & 4,053 \\
\hline $\mathrm{CaCl}_{2} \cdot 2 \mathrm{H}_{2} \mathrm{O}$ & 440 & 440 & 440 & 440 & 440 & 440 & 44 & 88 & 220 & 880 & 2,200 & 440 & 440 & 440 & 440 \\
\hline $\mathrm{KNO}_{3}$ & 1,900 & 190 & 380 & 950 & 1,900 & 1,900 & 1,900 & 1,900 & 1,900 & 1,900 & 1,900 & 190 & 380 & 950 & 1900 \\
\hline $\mathrm{KH}_{2} \mathrm{PO}_{4}$ & 170 & 17 & 34 & 85 & 170 & 170 & 170 & 170 & 170 & 170 & 170 & 170 & 170 & 170 & 170 \\
\hline $\mathrm{NaH}_{2} \mathrm{PO}_{4}{ }^{\mathrm{y}}$ & 0 & 135 & 120 & 75 & 0 & 0 & 0 & 0 & 0 & 0 & 0 & 0 & 0 & 0 & 0 \\
\hline $\mathrm{KCl}^{\mathrm{z}}$ & 0 & 0 & 0 & 0 & 1,495 & 5,980 & 0 & 0 & 0 & 0 & 0 & 1,261 & 1,121 & 701 & 0 \\
\hline
\end{tabular}

${ }^{\mathrm{x}}$ Represents $\mathrm{K}$ at $783 \mathrm{mg} / \mathrm{liter}, \mathrm{N}$ at $841 \mathrm{mg} / \mathrm{liter}$, and $\mathrm{Ca}$ at $121 \mathrm{mg} /$ liter, which is their normal concentration in Murashige and Skoog (MS) medium.

${ }^{y}$ Is not normally part of MS medium but was added to maintain normal phosphorus concentration when $\mathrm{K}$ was decreased in $\mathrm{KH}_{2} \mathrm{PO}_{4}$ at $\mathrm{K}_{\text {concentrations of }}$ 78,157 , and $391 \mathrm{mg} / \mathrm{liter}$.

${ }^{\mathrm{z}}$ Is not normally part of MS medium but was added to increase $\mathrm{K}$ concentrations to 1,565 and 3,913 $\mathrm{mg} /$ liter and also to maintain normal $\mathrm{K}$ concentrations when $\mathrm{N}$ was decreased using $\mathrm{KNO}_{3}$ to $\mathrm{N}$ concentrations of 84,168 , and $420 \mathrm{mg} / \mathrm{liter}$. 
pseudostem. Control plantlets were inoculated with sterile distilled water. The plantlets were then placed onto fresh medium of the same nutrient concentrations under which they were being cultured before inoculation. Each plantlet was placed singly in a glass culture jar containing $45 \mathrm{ml}$ of medium. The plantlets received a 14-h photoperiod provided by fluorescent tubes $\left(94 \mu \mathrm{mol} \mathrm{m} \mathrm{m}^{-2} \mathrm{~s}^{-1}\right)$ and maintained at $26 \pm 2{ }^{\circ} \mathrm{C}$. They were then observed for another 13 weeks. Data were recorded on incubation period (number of days from inoculation to the appearance of first symptoms of stem and leaf chlorosis and necrosis), disease incidence (percentage of plantlets showing symptoms), time taken from first appearance of symptoms to complete collapse of the pseudostem of the symptomatic plantlet (death), and percent death of the symptomatic plantlets. In order to replenish the nutrients, the surviving plantlets were transferred onto fresh medium of the same nutrient concentration every 4 weeks. In total, for each nutrient concentration, there were 15 plantlets per cultivar placed. The experiment was repeated three times, totaling, overall, 45 plantlets per cultivar for each nutrient concentration. This was done for all the three nutrients.

Reisolation of $X$. campestris pv. musacearum from symptomatic and surviving nonsymptomatic plantlets. To confirm the cause of disease symptoms, reisolation of $X$. campestris pv. musacearum was carried out on the symptomatic plantlets using YPGA medium. Reisolation of $X$. campestris pv. musacearum was also carried out from the surviving nonsymptomatic plantlets to check the presence or absence of X. campestris pv. musacearum. After 13 weeks post inoculation, a sample consisting of one-third of the surviving plantlets from each nutrient concentration was taken for reisolation of $X$. campestris pv. musacearum. Each plantlet was divided into four parts; leaves, upper pseudostem, lower pseudostem (region of inoculation), and corm. These parts were used for $X$. campestris pv. musacearum reisolation by macerating and plating onto YPGA medium. The confirmation of $X$. campestris pv. musacearum colonies was through comparison by morphological cultural characteristics on YPGA medium.

Data analysis. Data from tissue nutrient analysis was log transformed and subjected to linear regression whereas that on wilt incidence (presence or absence data) was subjected to logistic regression analysis. Data on incubation period and time taken for symptomatic plantlets to die were also log transformed and sub- jected to analysis of variance. Differences in the incidence means were separated using a Dunn Sidak correction and those for incubation period and time taken for symptomatic plantlets to die by Tukey's Studentized range test (version. 9.2; SAS Institute, Inc.).

\section{Results}

Culture of banana plantlets to varied nutrient concentrations in MS medium. The different media with the varied nutrient concentrations supported growth of the different banana cultivars, giving rise to plantlets of four to five leaves. At an $\mathrm{N}$ concentration of $84 \mathrm{mg} /$ liter, plantlets exhibited typical $\mathrm{N}$ deficiency symptoms of stunted growth and chlorotic lower leaves (Fig. 1C). The plantlets that received lower than normal nutrient concentrations had visibly thinner pseudostems than those that received the higher nutrient concentrations. The amount of each nutrient increased in the plantlet tissues as it was increased in the medium, showing significant linear relationships $(P<0.0001)$ (Fig. 2).

BXW development. Disease appeared as chlorosis and necrosis of the leaves and pseudostem. Control plantlets inoculated with sterile distilled water did not show any BXW symptoms (Fig. 3A). For each of the nutrients, wilt incidence and incubation period were highly significantly $(P<0.0001)$ affected by the nutrient concentration in the medium. The time taken for symptomatic plantlets to die was significantly $(P<0.0001)$ affected by nutrient concentration only for Ca but not for $\mathrm{K}$ and $\mathrm{N}$.

Effect of $K$ concentration on wilt incidence, incubation period, and time taken for symptomatic plantlets to die. Wilt incidence was significantly reduced $(P<0.0001)$ with increase in $\mathrm{K}$ concentration whereas the incubation period was significantly $(P<$ 0.0001 ) increased (Table 2). The reduction in wilt incidence was not influenced by cultivar; however, there was a significant interaction $(P<0.0001)$ between cultivar and $\mathrm{K}$ concentration. The incubation period was significantly influenced by cultivar $(P<$ $0.0001)$, for which there was also a significant interaction $(P<$ $0.0001)$ with $\mathrm{K}$ concentration. Nakitembe, which is moderately susceptible, showed the lowest wilt incidence and longest incubation period at the highest $\mathrm{K}$ concentrations of 1,565 and 3,913 $\mathrm{mg} /$ liter (Table 2). All the plantlets that developed symptoms eventually wilted, collapsed, and died. The time they took to die was not significantly influenced by $\mathrm{K}$ concentration but by cultivar
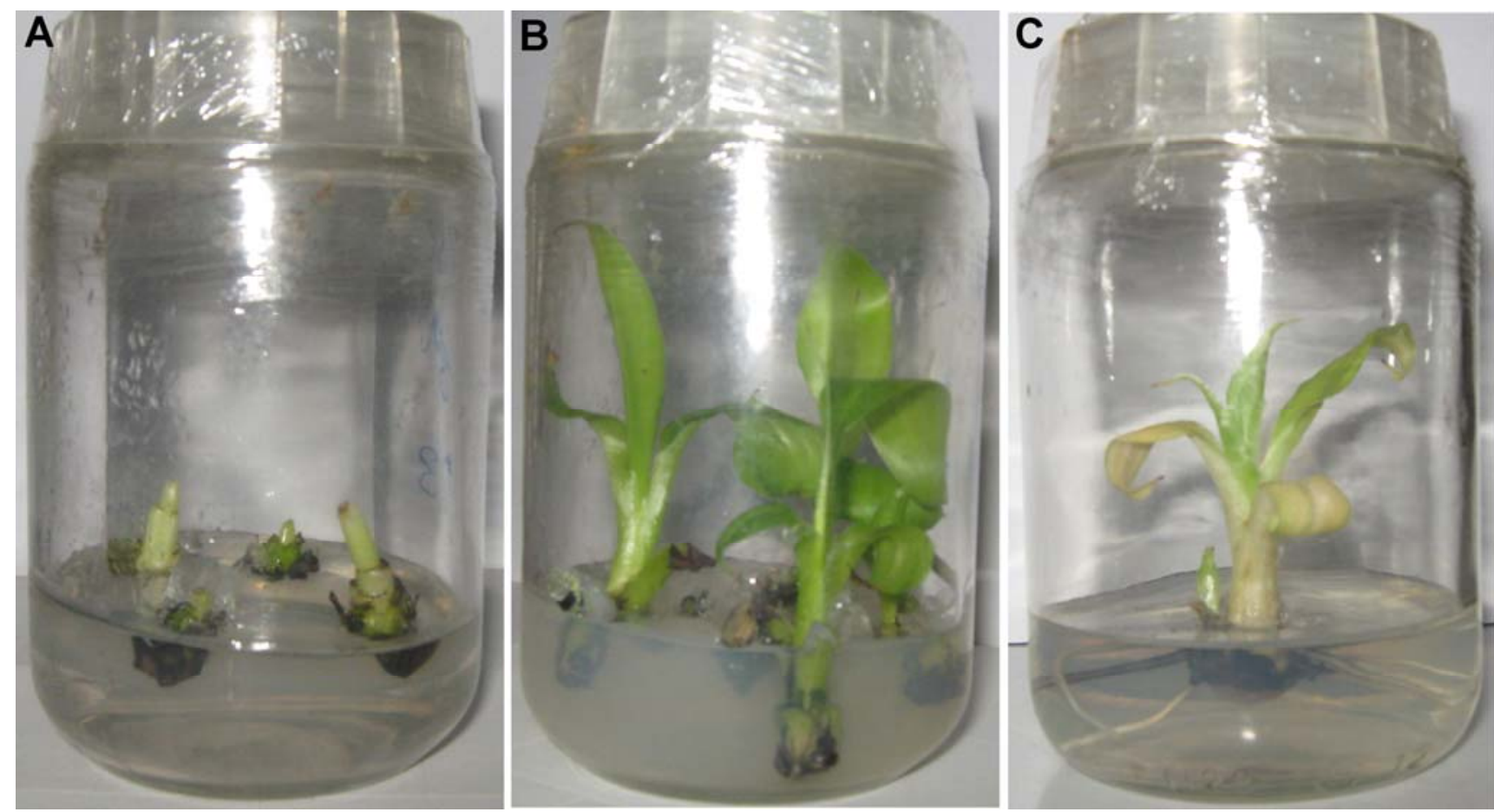

Fig. 1. In vitro technique. A, Four corms placed in each jar and B, after 4 weeks, each plantlet had three to four leaves. C, Nitrogen deficiency symptoms of stuntedness and leaf chlorosis on plantlets cultured with $\mathrm{N}$ concentration of $84 \mathrm{mg} /$ liter. 
$(P<0.0001)$; however, there was a significant interaction $(P=$ $0.0019)$ between the $\mathrm{K}$ concentration and cultivar.

Effect of Ca concentration on wilt incidence, incubation period, and time taken for symptomatic plantlets to die. The increase in $\mathrm{Ca}$ concentration in the medium significantly $(P<$ 0.0001) reduced the wilt incidence and increased the incubation period. The cultivar effect significantly influenced the wilt incidence $(P=0.0004)$ and incubation period $(P<0.0001)$ (Table 3$)$. The interaction between cultivar and $\mathrm{Ca}$ concentration was significant $(P<0.0001)$ only for the incubation period and not wilt incidence. The moderately resistant Nakitembe showed the lowest wilt incidence and incubation period at the highest $\mathrm{Ca}$ concentrations of 241 and $603 \mathrm{mg} /$ liter (Table 3). All the plantlets that developed symptoms eventually wilted, collapsed, and died. The time taken for the symptomatic plantlets to die was also significantly $(P<$ 0.0001 ) influenced by $\mathrm{Ca}$ concentration but not cultivar. In addition, there was no significant interaction between cultivar and $\mathrm{Ca}$ concentration for the time taken to die.

Effect of $\mathbf{N}$ concentration on wilt incidence, incubation period, and time taken for symptomatic plantlets to die. The increase in $\mathrm{N}$ concentration in the medium significantly $(P<0.0001)$ decreased the wilt incidence and increased the incubation period but did not influence the time taken for symptomatic plantlets to die. Cultivar had a significant $(P<0.0001)$ effect in each case, except in the wilt incidence. However, there was a significant interaction between cultivar and $\mathrm{N}$ concentration in wilt incidence $(P=$ $0.0017)$, incubation period $(P<0.0001)$, and time taken for symptomatic plantlets to die $(P=0.0109)$. The wilt incidence was not
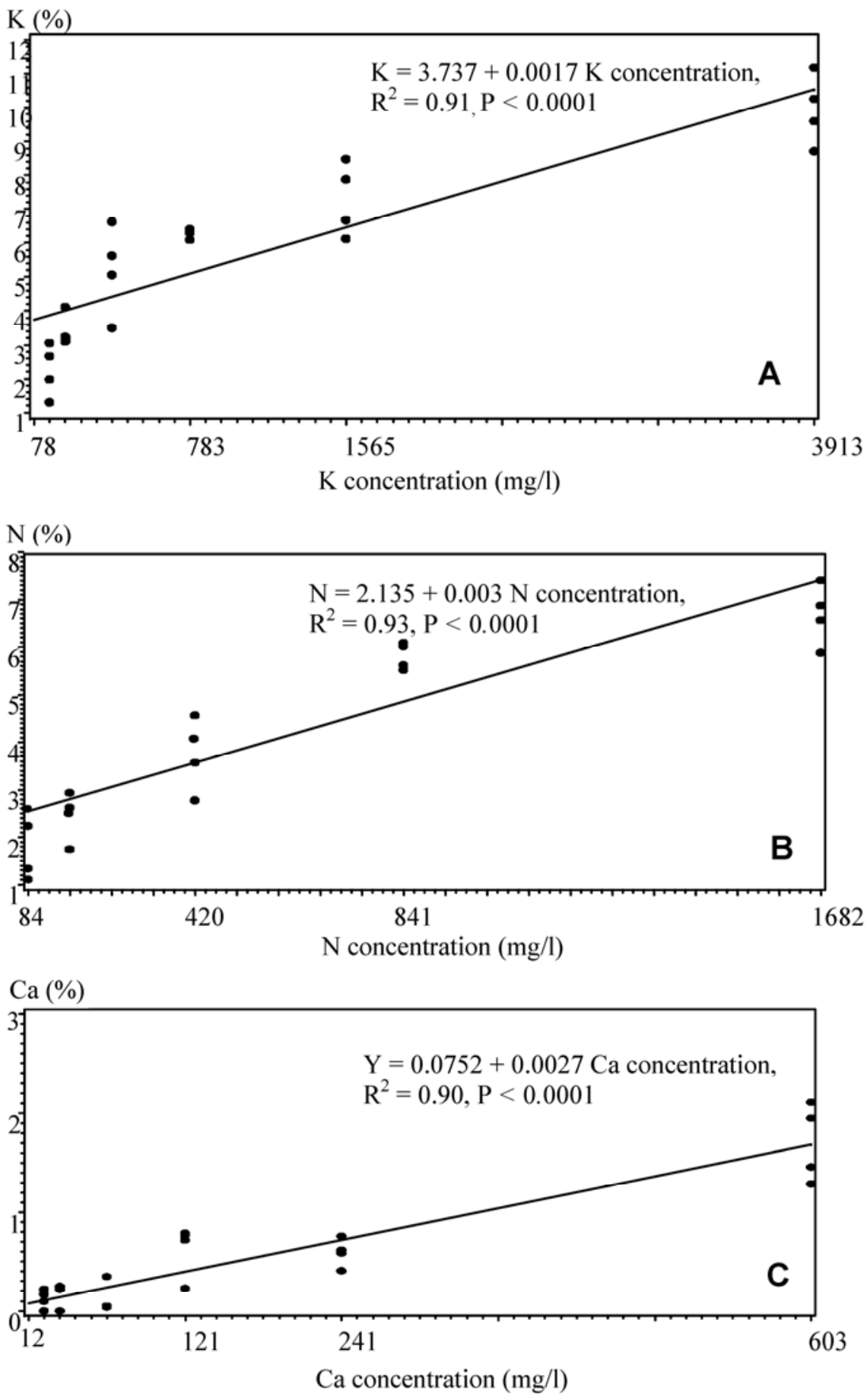

Fig. 2. Linear regression of nutrient concentration in medium on the nutrient concentration in plantlet tissues for A, potassium (K); B, nitrogen (N); and C, calcium (Ca) These data are based on a composite sample derived from three replicate experiments totaling to a dry weight of $0.4 \pm 0.1 \mathrm{~g}$. 
significantly affected by $\mathrm{N}$ concentration only in FHIA-17, for which overall incidence was $77 \%$. The lowest wilt incidence and the longest incubation period were recorded on the susceptible Mbwazirume at the highest $\mathrm{N}$ concentration of 1,682 mg/liter (Table 4). All the plantlets that developed symptoms eventually wilted, collapsed, and died.

Recovery of $X$. campestris pv. musacearum from banana plantlets after inoculation. Yellow colonies of $X$. campestris $\mathrm{pv}$. musacearum were recovered from plantlets that showed BXW symptoms of chlorosis and necrosis. However, from nonsymptomatic plantlets that survived up to the 13 th week without symptoms, even after having been previously inoculated with virulent $X$. campestris pv. musacearum, there was no consistency in the recovery of $X$. campestris pv. musacearum, even from the plantlets under the same nutrient concentration. $X$. campestris pv. musacearum was recovered from some plantlets and not from others. From those where $X$. campestris pv. musacearum was recovered, it was found present in the entire plantlet (all plant parts).

\section{Discussion}

Increased concentrations of $\mathrm{K}, \mathrm{Ca}$, and $\mathrm{N}$ in the medium subsequently increased those in the plantlet tissues and led to reduced wilt incidences and lengthened incubation periods. At lower nutri-
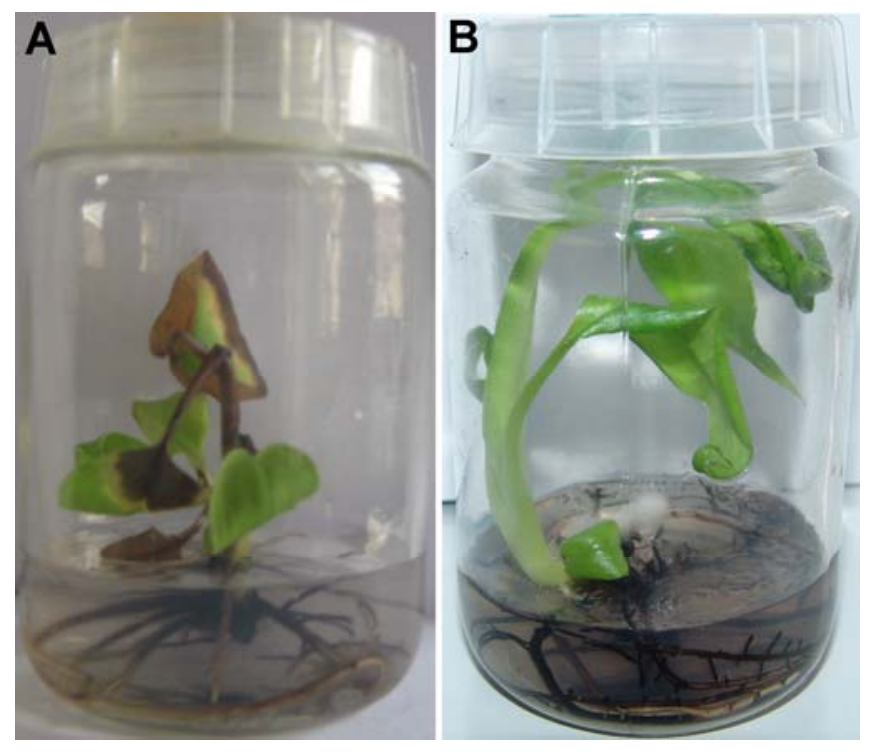

Fig. 3. Banana Xanthomonas wilt symptoms of $\mathbf{A}$, chlorosis and necrosis on the leaves and pseudostem of plantlets and $\mathbf{B}$, a nonsymptomatic plantlet. ent concentrations, the wilt incidences were higher and incubation periods were shorter, and vice versa. Similarly, Ssekiwoko et al. (36) and Tripathi et al. (40) also observed shorter incubation periods when BXW incidences were high in the case of more susceptible banana cultivars and vice versa in less susceptible ones. This shows that, in BXW disease, wilt incidences and incubation periods are always inversely related. Other nutrient studies in different plants have also observed similar trends with the same nutrients. McElhaney et al. (24) observed that cabbage plants (Brassica oleracea var. capitata) that received low $\mathrm{N}$ amounts developed black rot lesion symptoms caused by $X$. campestris pv. campestris more rapidly. In comparison, symptoms were delayed in those that received high levels of $\mathrm{N}$, and the chlorotic lesions were also reduced. Yamazaki (48) also observed delayed and reduced wilt caused by Ralstonia solanacearum in tomato (Lycopersicon esculentum) seedlings with higher $\mathrm{Ca}$ nutrition compared with lower $\mathrm{Ca}$ nutrition.

In this study, when media nutrient concentrations were increased from the normal concentrations, the wilt incidences were further reduced. On the other hand, decrease in media nutrient concentrations from the normal concentrations to the least concentration did not result in any significant increase in wilt incidences. Sumith and Bandara (38) also reported no difference in the zero rate and slightly higher rate of $\mathrm{K}$ nutrition which showed higher susceptibility of tobacco seedlings to damping-off caused by Pythium ultimum, Rhizoctonia solani, and Fusarium oxysporum f. sp. nicotianae than those that received much higher $\mathrm{K}$ nutrition rates. These observations demonstrate that, at low or deficient nutrient concentrations, slight increases in the nutrient concentrations may not reduce the plants' susceptibility to a particular disease. Therefore, it is important to include greater increases in nutrient concentrations, especially if the nutrient were already deficient, so as to obtain a substantial reduction in disease.

Regardless of the nutrient, plantlets that received higher concentrations also accumulated more in their tissues and showed less disease, suggesting that plant nutrition plays a role in disease reduction. These findings are in agreement with other studies where nutrient content in tissue increased with increased application and, consequently, conferred greater disease reduction $(11,30,48)$. In addition, Datnoff et al. (13) concludes that a wellnourished plant is more efficient in mobilizing defense factors than a poorly nourished plant and, therefore, is less susceptible to disease.

According to Huber (19) and Yamazaki (48), the greatest disease depression with nutrients is achieved with tolerant and resistant cultivars. This is because highly susceptible cultivars may not have the physiological defense responses regulated by a specific mineral ion whereas resistant cultivars may be highly efficient in nutrient

Table 2. Average wilt incidence at 13 weeks after inoculation (\%), incubation period (days), and time taken for symptomatic plantlets to die (days) of four cultivars regenerated under six potassium $(\mathrm{K})$ concentrations $^{\mathrm{x}}$

\begin{tabular}{|c|c|c|c|c|c|c|c|c|c|c|c|c|}
\hline \multirow[b]{2}{*}{ } & \multicolumn{4}{|c|}{ Incidence $(\%)^{\mathrm{y}}$} & \multicolumn{4}{|c|}{ Incubation period $(\text { days })^{\mathrm{z}}$} & \multicolumn{4}{|c|}{ Time taken to die (days) ${ }^{\mathrm{z}}$} \\
\hline & 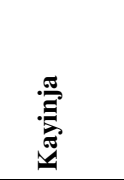 & $\stackrel{\Xi}{\Xi}$ & 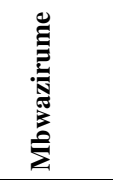 & 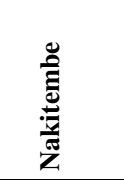 & 首 & $\underset{\Xi}{\Xi}$ & 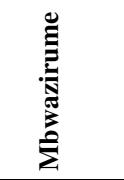 & 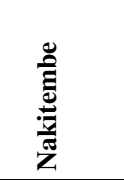 & 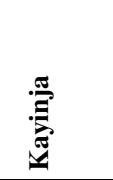 & 离 & 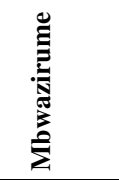 & 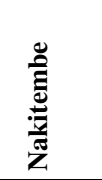 \\
\hline 78 & $100 \mathrm{~b}$ & $96 \mathrm{~b}$ & $87 \mathrm{c}$ & $98 \mathrm{c}$ & $14 \mathrm{~d}$ & $19 \mathrm{~b}$ & $24 \mathrm{~b}$ & $20 \mathrm{c}$ & $14 \mathrm{~b}$ & $18 \mathrm{ab}$ & $20 \mathrm{a}$ & $20 \mathrm{a}$ \\
\hline 157 & $91 \mathrm{~b}$ & $89 \mathrm{~b}$ & $87 \mathrm{c}$ & $96 \mathrm{c}$ & $18 \mathrm{bc}$ & $21 \mathrm{~b}$ & $25 \mathrm{~b}$ & $20 \mathrm{c}$ & $15 a b$ & $20 \mathrm{ab}$ & $18 \mathrm{a}$ & $21 \mathrm{a}$ \\
\hline 391 & $84 \mathrm{~b}$ & $93 \mathrm{~b}$ & $69 \mathrm{c}$ & $96 \mathrm{c}$ & $17 \mathrm{c}$ & $20 \mathrm{~b}$ & $22 \mathrm{~b}$ & $20 \mathrm{c}$ & $14 \mathrm{~b}$ & $18 \mathrm{ab}$ & $22 \mathrm{a}$ & $21 \mathrm{a}$ \\
\hline 783 & $77 \mathrm{~b}$ & $76 \mathrm{~b}$ & $73 \mathrm{bc}$ & $70 \mathrm{~b}$ & $20 \mathrm{~b}$ & $21 \mathrm{~b}$ & $23 \mathrm{~b}$ & $21 \mathrm{c}$ & $18 \mathrm{ab}$ & $17 \mathrm{~b}$ & $18 \mathrm{a}$ & $18 \mathrm{a}$ \\
\hline 1,565 & $40 \mathrm{ab}$ & $33 \mathrm{a}$ & $53 \mathrm{ab}$ & $27 \mathrm{a}$ & $25 \mathrm{ab}$ & $28 \mathrm{a}$ & $33 \mathrm{a}$ & $32 \mathrm{~b}$ & $20 \mathrm{a}$ & $22 a b$ & $20 \mathrm{a}$ & $20 \mathrm{a}$ \\
\hline 3,913 & $30 \mathrm{da}$ & $27 \mathrm{a}$ & $31 \mathrm{a}$ & $7 \mathrm{a}$ & $27 \mathrm{a}$ & $30 \mathrm{a}$ & $35 \mathrm{a}$ & $42 \mathrm{a}$ & $17 \mathrm{ab}$ & $24 \mathrm{a}$ & $18 \mathrm{a}$ & $20 \mathrm{a}$ \\
\hline$\chi^{2}$ & 96.11 & 105.46 & 47.06 & 176.79 & & & $\ldots$ & $\ldots$ & $\ldots$ & & & \\
\hline$F$ & $\ldots$ & & & $\ldots$ & $\geq 24.62$ & $\geq 11.58$ & $\geq 24.76$ & $\geq 42.18$ & $\geq 3.94$ & $\geq 2.89$ & $\geq 0.42$ & $\geq 1.31$ \\
\hline$P$ & $<0.0001$ & $<0.0001$ & $<0.0001$ & $<0.0001$ & $<0.0001$ & $<0.0001$ & $<0.0001$ & $<0.0001$ & $=0.0020$ & $=0.0155$ & $=0.8351$ & $=0.2610$ \\
\hline
\end{tabular}

${ }^{\mathrm{x}}$ Data are derived from three replicate experiments which consisted of 15 plantlets each.

${ }^{y}$ For each cultivar, figures followed by the same letter are not significantly different at $P \leq 0.0034$ (Dunn-Sidak correction factor).

${ }^{\mathrm{z}}$ For each cultivar, figures followed by the same letter are not significantly different at $P \leq 0.05$ (Tukey's Studentized range test). 
uptake or function. In this study, the moderately susceptible Nakitembe showed the lowest wilt incidences and longest incubation periods at both the highest $\mathrm{Ca}$ and $\mathrm{K}$ concentrations. Other nutrient studies have also showed resistant cultivars expressing better disease resistance at higher nutrient concentrations $(31,48)$.

All the plantlets that developed disease eventually died within 2 to 3 weeks and were not universally dependent on nutrient concentration. In other banana diseases such as the black and yellow Sigatoka, a symptomatic plant may not necessarily die, which allows it to yield a small bunch depending on the level of disease severity (41). In contrast, however, due to the fruit rotting nature of BXW, symptomatic plants do not give any edible fruit (42). Therefore, in $\mathrm{BXW}$, the time taken for a banana plant to survive with symptoms may not be of relevance because it does not relate to yield, especially if the fruit is affected. Instead, wilt incidence and incubation period are better parameters in disease measurement and predicting yield that may result despite the occurrence of disease.

The reduction in susceptibility to BXW due to $\mathrm{K}$ nutrition that has been observed in this study relates to other studies where diseases caused by Xanthomonads have been depressed by K. These include angular leaf spot of cotton (X. malvacearum), bacterial blight of rice (X. oryzae) (30), Xanthomonas blight of Syngonium podophyllum (X. campestris pv. syngoni) (10), and bacterial blight of cassava (caused by $X$. axonopodis pv. manihotis) (1). Higher $\mathrm{N}$ levels have also suppressed other Xanthomonad-caused diseases $(10,11)$. However, in others, high $\mathrm{N}$ levels increased diseases such as bacterial blight severity of rice (X. oryzae) (31), leaf blight of onion ( $X$. axonopodis pv. allii) (17), and black Sigatoka of banana (Mycospharella fijiensis) (2).

Recovery of $X$. campestris pv. musacearum from symptomatic plantlets indicated that $X$. campestris pv. musacearum was, indeed, the cause of BXW symptoms. This study did not directly investigate the mechanism of disease resistance as influenced by nutrients. However, the inconsistency in recovery of $X$. campestris pv. musacearum from the previously inoculated yet nonsymptomatic plantlets could suggest that banana, using nutrients, may employ more than one defense mechanism. The presence of $X$. campestris pv. musacearum in such nonsymptomatic plantlets shows that it is able to colonize the plantlets and yet unable to cause disease symptoms. This could result from the plantlet detoxifying the pathogenicity and virulence factors secreted by $X$. campestris pv. $m u$ sacearum. It could also result from $X$. campestris $\mathrm{pv}$. musacearum being limited to an endophytic growth because it cannot reach the threshold levels where it can cause disease $(2,8)$. In such cases, the bacteria will survive but not be able to cause disease, which could account for their recovery in nonsymptomatic plantlets. Recovery of $X$. campestris pv. musacearum in nonsymptomatic plantlets may also be a case of latent infection $(2,33)$ which, if it occurred under field conditions, would present another means of dissemination of the bacteria, if such suckers were used as propagation material in other fields. However, this can only be the case if such bacteria can still be infective so as to cause BXW symptoms and if they can persist for long periods endophytically in the banana plants and its suckers.

Table 3. Average wilt incidence at 13 weeks after inoculation (\%), incubation period (days), and time taken for symptomatic plantlets to die (days) of four cultivars regenerated under six calcium $(\mathrm{Ca})$ concentrations $^{\mathrm{x}}$

\begin{tabular}{|c|c|c|c|c|c|c|c|c|c|c|c|c|}
\hline \multirow[b]{2}{*}{ 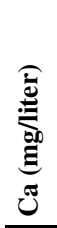 } & \multicolumn{4}{|c|}{ Incidence $(\%)^{y}$} & \multicolumn{4}{|c|}{ Incubation period $(\text { days })^{\mathrm{z}}$} & \multicolumn{4}{|c|}{ Time taken to die (days) $^{\mathrm{z}}$} \\
\hline & 首 & $\stackrel{5}{\Xi}$ & 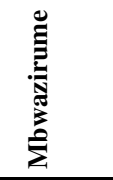 & 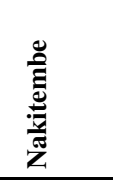 & 吾 & 音 & 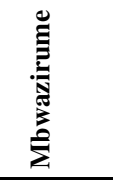 & 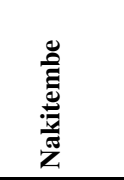 & 莺 & 氞 & 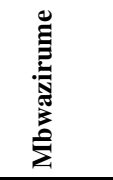 & 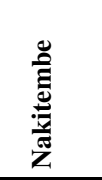 \\
\hline 12 & $73 \mathrm{~b}$ & $74 \mathrm{~b}$ & $60 \mathrm{~b}$ & $62 \mathrm{~b}$ & $28 \mathrm{~b}$ & $23 \mathrm{~b}$ & $25 \mathrm{bc}$ & $29 \mathrm{~b}$ & $14 \mathrm{~b}$ & $15 \mathrm{ab}$ & $15 \mathrm{ab}$ & $13 \mathrm{c}$ \\
\hline 24 & $88 \mathrm{~b}$ & $77 \mathrm{~b}$ & $60 \mathrm{~b}$ & $68 \mathrm{~b}$ & $26 \mathrm{~b}$ & $24 \mathrm{~b}$ & $29 \mathrm{ab}$ & $28 \mathrm{~b}$ & $14 \mathrm{~b}$ & $15 \mathrm{ab}$ & $14 \mathrm{~b}$ & $14 \mathrm{c}$ \\
\hline 60 & $80 \mathrm{~b}$ & $76 \mathrm{~b}$ & $67 \mathrm{~b}$ & $76 \mathrm{~b}$ & $28 \mathrm{~b}$ & $24 \mathrm{~b}$ & $28 a b c$ & $29 \mathrm{~b}$ & $17 \mathrm{a}$ & $13 \mathrm{~b}$ & $14 \mathrm{~b}$ & $15 \mathrm{bc}$ \\
\hline 121 & $77 \mathrm{~b}$ & $76 b$ & $73 \mathrm{~b}$ & $70 \mathrm{~b}$ & $20 \mathrm{c}$ & $21 \mathrm{~b}$ & $23 \mathrm{c}$ & $21 \mathrm{c}$ & $18 \mathrm{a}$ & $18 \mathrm{a}$ & $18 \mathrm{ab}$ & $18 \mathrm{~b}$ \\
\hline 241 & $40 \mathrm{a}$ & $47 \mathrm{a}$ & $47 \mathrm{ab}$ & $16 \mathrm{a}$ & $36 a$ & $31 \mathrm{a}$ & $30 \mathrm{ab}$ & $35 \mathrm{ab}$ & $22 \mathrm{a}$ & $16 \mathrm{ab}$ & $19 \mathrm{a}$ & $20 \mathrm{ab}$ \\
\hline 603 & $20 \mathrm{a}$ & $17 \mathrm{a}$ & $17 \mathrm{a}$ & $4 \mathrm{a}$ & $38 \mathrm{a}$ & $35 \mathrm{a}$ & $32 \mathrm{a}$ & $47 \mathrm{a}$ & $18 \mathrm{a}$ & $16 a b$ & $17 \mathrm{ab}$ & $25 \mathrm{a}$ \\
\hline$\chi^{2}$ & 68.74 & 55.30 & 36.30 & 95.89 & & & & & & & & \\
\hline$\tilde{F}$ & $\ldots$ & & & & $\geq 33.96$ & $\geq 16.93$ & $\geq 4.84$ & $\geq 19.56$ & $\geq 2.52$ & $\geq 2.59$ & $\geq 3.50$ & $\geq 5.48$ \\
\hline$P$ & $<0.0001$ & $<0.0001$ & $<0.0001$ & $<0.0001$ & $<0.0001$ & $<0.0001$ & $=0.0004$ & $<0.0001$ & $=0.0316$ & $=0.0277$ & $=0.0052$ & $=0.0001$ \\
\hline
\end{tabular}

${ }^{\mathrm{x}}$ Data are derived from three replicate experiments which consisted of 15 plantlets each.

y For each cultivar, figures followed by the same letter are not significantly different at $P \leq 0.0034$ (Dunn-Sidak correction factor).

${ }^{\mathrm{z}}$ For each cultivar, figures followed by the same letter are not significantly different at $P \leq 0.05$ (Tukey's Studentized range test).

Table 4. Average wilt incidence at 13 weeks after inoculation (\%), incubation period (days), and time taken for symptomatic plantlets to die (days) of four cultivars regenerated under five nitrogen $(\mathrm{N})$ concentrations $^{\mathrm{x}}$

\begin{tabular}{|c|c|c|c|c|c|c|c|c|c|c|c|c|}
\hline \multirow[b]{2}{*}{ 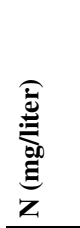 } & \multicolumn{4}{|c|}{ Incidence $(\%)^{\mathrm{y}}$} & \multicolumn{4}{|c|}{ Incubation period (days) ${ }^{\mathrm{z}}$} & \multicolumn{4}{|c|}{ Time taken to die (days) ${ }^{\mathrm{z}}$} \\
\hline & 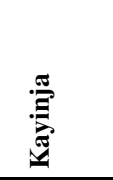 & 昰 & 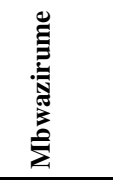 & 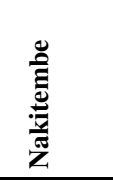 & 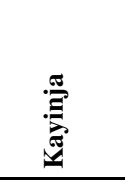 & 吾 & 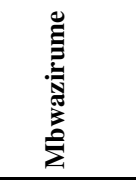 & 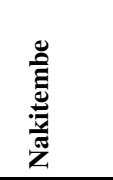 & 緎 & $\stackrel{\Xi}{I}$ & 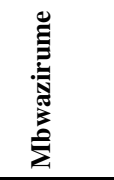 & 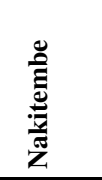 \\
\hline 84 & $84 \mathrm{~b}$ & $76 \mathrm{a}$ & $93 \mathrm{c}$ & $82 \mathrm{~b}$ & $27 \mathrm{~b}$ & $26 \mathrm{a}$ & $28 \mathrm{~b}$ & $20 \mathrm{~b}$ & $12 \mathrm{~b}$ & $15 \mathrm{ab}$ & $19 \mathrm{a}$ & $19 \mathrm{a}$ \\
\hline 168 & $84 \mathrm{~b}$ & $76 \mathrm{a}$ & $87 \mathrm{bc}$ & $89 \mathrm{~b}$ & $26 \mathrm{bc}$ & $23 \mathrm{ab}$ & $29 \mathrm{~b}$ & $21 \mathrm{~b}$ & $17 \mathrm{ab}$ & $14 \mathrm{~b}$ & $18 \mathrm{a}$ & $19 \mathrm{a}$ \\
\hline 420 & $96 \mathrm{~b}$ & $91 \mathrm{a}$ & $67 \mathrm{~b}$ & $84 \mathrm{~b}$ & $24 \mathrm{~cd}$ & $22 \mathrm{ab}$ & $26 \mathrm{bc}$ & $20 \mathrm{~b}$ & $14 \mathrm{ab}$ & $15 \mathrm{ab}$ & $18 \mathrm{a}$ & $21 \mathrm{a}$ \\
\hline 841 & $77 \mathrm{~b}$ & $76 \mathrm{a}$ & $73 \mathrm{bc}$ & $70 \mathrm{ab}$ & $20 \mathrm{~d}$ & $21 \mathrm{~b}$ & $25 c$ & $21 \mathrm{~b}$ & $18 \mathrm{a}$ & $18 \mathrm{a}$ & $19 \mathrm{a}$ & $18 \mathrm{a}$ \\
\hline 1,682 & $42 \mathrm{a}$ & $67 \mathrm{a}$ & $36 \mathrm{a}$ & $44 \mathrm{a}$ & $36 \mathrm{a}$ & $25 \mathrm{a}$ & $38 \mathrm{a}$ & $25 \mathrm{a}$ & $13 a b$ & $17 \mathrm{a}$ & $24 \mathrm{a}$ & $21 \mathrm{a}$ \\
\hline$\chi^{2}$ & 40.12 & 8.78 & 45.08 & 28.61 & & & & & & & & \\
\hline$\tilde{F}$ & & & & & $\geq 22.51$ & $\geq 4.76$ & $\geq 10.36$ & $\geq 5.23$ & $\geq 3.50$ & $\geq 2.64$ & $\geq 1.13$ & $\geq 0.35$ \\
\hline$P$ & $<0.0001$ & $=0.0667$ & $<0.0001$ & $<0.0001$ & $<0.0001$ & $<0.0012$ & $<0.0001$ & $=0.0006$ & $=0.0091$ & $=0.0354$ & $=0.3429$ & $=0.8441$ \\
\hline
\end{tabular}

${ }^{\mathrm{x}}$ Data are derived from three replicate experiments which consisted of 15 plantlets each.

${ }^{y}$ For each cultivar, figures followed by the same letter are not significantly different at $P \leq 0.0051$ (Dunn-Sidak correction factor).

${ }^{\mathrm{z}}$ For each cultivar, figures followed by the same letter are not significantly different at $P \leq 0.05$ (Tukey's Studentized range test). 
The absence of $X$. campestris pv. musacearum may also be explained by the plantlet employing phytoalexins to kill the bacteria. Nonrecovery of $X$. campestris pv. musacearum was also observed in the resistant Musa balbisiana species which is able to recover from BXW symptoms (36). In vascular wilt diseases, the plant may respond by forming tyloses which prevent further movement of the pathogen (33). However, in this study, the presence of $X$. campestris pv. musacearum in all plant parts of the nonsymptomatic plantlets from which it was recovered suggests that part of the defense mechanism that banana employs in disease resistance as induced by nutrients may not involve restricting the movement of $X$. campestris pv. musacearum.

This study has demonstrated that, using the in vitro technique, higher concentrations of $\mathrm{K}, \mathrm{Ca}$, and $\mathrm{N}$ strongly reduced susceptibility to BXW, as indicated by the lowered wilt incidences and longer incubation periods. For the first time, the study lays a background for the possible use of nutrient-based approaches such as fertilizer use in the future management of BXW. However, because the natural soil environment presents a diverse interaction of several factors such as physical, chemical, and biotic properties that are absent in the in vitro technique, our results only provide a basis for investigating the use of these nutrients in an in vivo system. Therefore, it is recommended that pot and field trials be carried out. Other methods of soil nutrient management to provide nutrients should also be studied so as to check the similarities in results. Such methods may include interplanting banana with legumes to provide nitrogen or use of compost, ash, or household and animal manure. It is also recommended that the mechanisms of disease resistance as influenced by nutrients and the resultant interaction with $X$. campestris pv. musacearum be investigated to improve our understanding on the basis of use of nutrients for disease management.

\section{Acknowledgments}

M Atim was awarded a scholarship from the Belgium Technical Co-operation toward the completion of a masters' degree. We thank T. Dubios (International Institute of Tropical Agriculture [IITA]), S. B. Mukasa (Makerere University, Kampala), and T. Godfrey (IITA) for reviewing the manuscript.

\section{Literature Cited}

1. Adeniji, M. O., and Obigbesan, G. O. 1976. The effect of the potassium nutrition on the bacterial wilt of cassava. Niger. J. Plant Prot. 2:1-3.

2. Agrios, G. N. 2005. Plant Pathology, 5th ed. Elsevier-Academic Press, London.

3. Aritua, V., Nanyonjo, A., Kumakech, F., and Tushemereirwe, W. 2007. RepPCR reveals a high genetic homogeneity among Ugandan isolates of Xanthomonas campestris pv. musacearum. Afr. J. Biotechnol. 6:179-183.

4. Bekunda, M. 1999. Farmers' responses to soil fertility decline in bananabased cropping systems of Uganda. In: Managing Africa's Soils, Series No. 4. Russell Press, Nottingham, UK. http://pubs.iied.org/pdfs/7397IIED.pdf

5. Bekunda, M. A., Nkonya, E., Mugendi, D., and Msaky, J. J. 2004. Soil fertility status, management and research in East Africa. East Afr. J. Rural Dev. 20:94-112.

6. Bekunda, M. A., Wortmann, C. S., Bwamiki, D. P., and Okwakol, M. 2003. Potentials and challenges of soil fertility management in the banana-based cropping systems of Eastern Africa. Pages 123-145 in: Soil Fertility Management in Africa: A Regional Perspective. M. P. Gichuru, A. Bationo, M. A. Bekunda, H. C. Goma, P. L. Mafongonya, D. N. Mugendi, H. M. Murwira, S. M. Nandwa, P. Nyathi, and M. J. Swift, eds. Academy Science Publishers (ASP), Nairobi, Kenya.

7. Biruma, M., Pillay, M., Tripathi, L., Blomme, G., Abele, S., Mwangi, M., Bandyopadhyay, R., Muchunguzi, P., Kassim, S., Nyine, M., Turyagyenda, L., and Eden-Green, S. 2007. Banana Xanthomonas wilt: a review of the disease, management strategies and future research directions. Afr. J. Biotechnol. 6:953-962.

8. Bosgelmez-Tinaz, G. 2003. Quorum sensing in gram-negative bacteria. Turk. J. Biol. 27:85-93.

9. Carter, B. A., Reeder, R., Mgenzi, S. R., Kinyua, Z. M., Mbaka, J. N., Doyle, K., Nakato, V., Mwangi, M., Beed, F., Aritua, V., Lewis Ivey, M. L., Miller, S. A., and Smith, J. J. 2010. Identification of Xanthomonas vasicola (formerly X. campestris pv. musacearum), causative organism of banana Xanthomonas wilt in Tanzania, Kenya and Burundi. Plant Pathol. 59:403.

10. Chase, A. R. 1989. Effect of nitrogen and potassium fertilizer rates on severity of Xanthomonas blight of Syngonium podophyllum. Plant Dis. 73:972-975.

11. Chase, A. R., and Poole, R. T. 1987. Effects of fertilizer rates on severity of
Xanthomonas leaf spot of Schefflera and dwarf Schefflera. Plant Dis. 71:527-529.

12. Daniells, J. W. 2009. Global banana disease management-getting serious with sustainability and food security. Pages 411-416 in: Proc. Int. Symp. Banana Crop Prot. Sustain Crop Prod. Improved Livelihoods. D. Jones, and I. Van den Bergh, eds. Acta Hortic. 828. ISHS, Leuven, Belgium.

13. Datnoff, L. E., Elmer, W. H., and Huber, D. M., eds. 2007. Pages 139-146 in: Mineral Nutrition and Plant Disease. American Phytopathological Society, St. Paul, MN.

14. Dordas, C. 2008. Role of nutrients in controlling plant diseases in sustainable agriculture. A review. Agron. Sustain. Dev. 28:33-46.

15. FAOSTAT Agriculture Data. 2003. http://faostat.fao.org

16. FAOSTAT Agriculture Data. 2008. http://faostat.fao.org

17. Gent, D. H., and Schwartz, H. F. 2005. Effect of nitrogen fertilization and seed contamination on epiphytic populations of Xanthomonas axonopodis pv. allii and development of Xanthomonas leaf blight of onion. Plant Health Prog. Online publication. doi:10.1094/PHP-2005-0331-01-RS

18. Graham, M. J., Heavner, D. L., Nickell, C. D., and Widholm, J. M. 1993. Response of soybean genotypes to boron, zinc and manganese deficiency in tissue culture. Plant Soil 150:307-310.

19. Huber, D. M., and Haneklaus, S. 2007. Managing nutrition to control plant disease. Landbauforsch. Voelkenrode 4:313-322.

20. International Food Policy Research Institute (IFPRI), 2004. Economic benefits of mitigating major production constraints affecting banana in Uganda: an industry-scale analysis. In: Strategic Criteria for Rural Investments in Productivity, Brief 9. www.foodnet.cgiar.org/scrip/docs\& databases/SCRIP_Briefs/

21. Jimenez, F. I. M. 2008. Effect of the nutritional status of banana (Musa spp.) on leaf disease infestation by Mycosphaerella fijiensis Morelet in Ecuador. Ph.D. dissertation, Katholieke Universiteit Leuven, Leuven, Belgium. http://biw.kuleuven.be/DTP/TRO/PhD-TRPL-pdf/PhD-MaJimenez.pdf

22. Kagezi, G. H., Kangire, A., Tushemereirwe, W., Bagamba, F., Kikulwe, E. Muhangi, J., Gold, C. S., and Ragama, P. 2006. Banana bacterial wilt incidence in Uganda. Afr. Crop Sci. J. 14:83-91.

23. Karugaba, A., and Kimaru, G. 1999. Banana production in Uganda: an essential food and cash crop. Technical Handbook Series 18, RELMA, Nairobi, Kenya.

24. McElhaney, R., Alvarez, A. M., and Kado, C. I. 1998. Nitrogen limits Xanthomonas campestris pv. campestris invasion of the host xylem. Physiol. Mol. Plant Pathol. 52:15-24.

25. Murashige, T., and Skoog, F. 1962. A revised medium for rapid growth and bioassays with tobacco tissue cultures. Physiol. Plant. 15:473-497.

26. Mwangi, M., and Nakato, V. 2007. Key factors responsible for the Xanthomonas wilt epidemic on banana in East and Central Africa. Pages 395404 in: Proc. Int. Symp. Banana Crop Prot. Sustain. Crop Prod. Improved Livelihoods. D. Jones, and I. Van den Bergh, eds. Acta Hortic. 828. ISHS, Leuven, Belgium

27. Ndungo, V., Bakelana, K., Eden-Green, S., and Blomme, G. 2004. An outbreak of Banana Xanthomonas wilt (Xanthomonas campestris pv. musacearum) in the Democratic Republic of Congo. Infomusa 13:43-44.

28. Nyombi, K., Van Asten, P. J. A., Corbeels, M., Taulya, G., Leffelaar, P. A., and Giller, K. E. 2010. Mineral fertilizer response and nutrient use efficiencies of East African highland banana (Musa spp., AAA-EAHB, cv. Kisansa). Field Crops Res. 117:38-50.

29. Okalebo, J. R., Gathua, K. W., and Woomer, P. L. 1993. Laboratory methods of soil and plant analysis: a working manual. Soil Sci. Soc. East Afr. Tech. Publ. No. 1. TSBF Programme, UNESCO-ROSTA. Nairobi, Kenya.

30. Prabhu, S. A., Fageria, N. K., Huber, D. M., and Rodrigues, F. A. 2007 Potassium and plant diseases. Pages 57-68 in: Mineral nutrition and plant disease. E. L. Datnoff, W. H. Elmer, and D. M. Huber, eds. American Phytopathological Society, St. Paul, MN

31. Reddy, A. P. K., Katyal, J. C., Rouse, D. I., and MacKenzie, D. R. 1979. Relationship between nitrogen fertilization, bacterial leaf blight severity, and yield of rice. Phytopathology 69:970-973.

32. Reeder, R. H., Opolot, O., Muhinyuza, J. B., Aritua, V., Crozier, J., and Smith, J. 2007. Presence of banana bacterial wilt (Xanthomonas campestris pv. musacearum) in Rwanda. New Dis. Rep. 14. Online publication. doi:10.1111/j.1365-3059.2007.01640.x

33. Schumann, G. L., and D'Arcy, C. J. 2006 Essential Plant Pathology. American Phytopathological Society, St. Paul, MN

34. Smithson, P. C., McIntyre, B. D., Gold, C. S., Ssali, H., and Kashaija, I. N. 2001. Nitrogen and potassium fertilizer vs. nematode and weevil effects on yield and foliar nutrient status of banana in Uganda. Nutr. Cycl. Agroecosyst. 59:239-250.

35. Smithson, P. C., McIntyre, B. D., Gold, C. S., Ssali, H., Night, G., and Okech, S. 2004. Potassium and magnesium fertilizers on banana in Uganda: yields, weevil damage, foliar nutrient status and DRIS analysis. Nutr. Cycl. Agroecosyst. 69:43-49.

36. Ssekiwoko, F., Tushemereirwe, W. K., Batte, M., Ragama, P. E., and Kumakech, A. 2006. Reaction of banana germplasm to inoculation with Xanthomonas campestris pv. musacearum. Afr. Crop. Sci. J. 14:151-155.

37. Stoinova, J., Phileva, S., Merakchyiska, M., and Paunova, S. 2007. Tolerance to high copper ions concentration in the nutrient medium of some Bulgarian barley cultivars. Barley Genet. Newsl. 37:47-49. 
38. Sumith, J. A., and Bandara, J. M. R. S. 2002. Effect of potassium on the development and severity of damping-off in tobacco (Nicotiana tabacum L.). Ann. Sri Lanka Dep. Agric. 4:327-335.

39. Tripathi, L., Mwangi, M., Abele, S., Aritua, V., Tushemereirwe, W. K., and Bandyopadhyay, R. 2009. Xanthomonas wilt: a threat to banana production in East and Central Africa. Plant Dis. 93:440-451.

40. Tripathi, L., Odipio, J., Tripathi, J. N., and Tusiime, G. 2008. A rapid technique for screening banana cultivars for resistance to Xanthomonas wilt. Eur. J. Plant Pathol. 121:9-19.

41. Tushemereirwe, W., Holderness, M., Gold, C. S., and Deadman, M. 1996. Effects of the leaf spot complex and leaf pruning on growth and yield in highland bananas: results of the first ratoon crop. Pages 335-341 in: Proc. Int. Conf. Banana and Plantain for Africa. K. Craenen., R. Ortiz, E. B. Karamura, and D. Vuylsteke., eds. Acta Hortic. 540. ISHS, Leuven, Belgium.

42. Tushemereirwe, W., Kangire, A., Smith, J., Ssekiwoko, F., Nakyanzi, M., Kataama, D., Musiitwa, C., and Karyajja, R. 2003. An outbreak of bacterial wilt on banana in Uganda. Infomusa 12:6-8.

43. Tushemereirwe, W. K., Okaasai, O., Kubiriba, J., Nankinga, C., Muhangi, J., Odoi, N., and Opio, F. 2006. Status of banana bacterial wilt in Uganda.
Afr. Crop Sci. J. 14:73-82.

44. Van Asten, P. J. A., Gold, C. S., Oketch, O. H., Gaidashova, S. V., Tushemereirwe, W. K., and De Waele, D. 2004. Soil quality problems in East African banana systems and their relation with other yield loss factors. Infomusa 13:20-24.

45. Wairegi, L. W. I., Van Asten, P. J. A., Tenywa, M. M., and Bekunda, M. A 2010. Abiotic constraints override biotic constraints in East African highland banana systems. Field Crop Res. 117:146-153.

46. Wheatley, A. O., Ahmad, M. H., and Asemota, H. N. 2003. Development of salt adaptation in In vitro greater yam (Dioscorea alata) plantlets. Invit. Cell Dev. Biol. Plant. 39:346-353.

47. Williams, R. R. 1991. Factors determining mineral uptake in vitro. Pages 165-169 in: Int. Symp. Plant Biotechnol. Contribution Plant Dev. Multiplication, Improvement. J. M. Mascherpa and C. H. Moncousin, eds. Acta Hortic. 289. ISHS, Leuven, Belgium.

48. Yamazaki, H. 2001. Relation between resistance to bacterial wilt and calcium nutrition in tomato seedlings. Jpn. Agric. Res. Q. 35:163-169.

49. Yirgou, D., and Bradbury, J. F. 1974. A note on wilt of banana caused by the enset wilt organism Xanthomonas musacearum. East Afr. Agric. For. J. 40:111-114. 